\title{
GMAW Esaslı Eklemeli İmalat İle Üretilen Düşük Karbonlu Çeliğin Mekanik Özellikleri
}

\author{
Mustafa GÜNAY ${ }^{*}$, a $\mathbb{D}$, İskender YEŞILDAĞ $\breve{b}^{\mathrm{b}}$ \\ ${ }^{a,{ }^{*}}$ Karabük Üniversitesi, Makine Mühendisliği Bölümü, 78050, Karabük, Türkiye \\ ${ }^{b}$ Karabük Üniversitesi, Lisansüstü Eğitim Enstitüsü, 78050, Karabük, Türkiye
}

MAKALE

BİLGISİ

Alınma: 08.09.2021

Kabul: $02.11 . .2021$

Anahtar Kelimeler:

Eklemeli imalat

Düșük karbonlu çelik

WAAM

Mekanik özellikler

Deformasyon hizı
$\ddot{\mathrm{öZ}}$

Tel ark eklemeli imalat, özellikle büyük ebatlı metal parçaların ekonomik üretimi ve nispeten yüksek biriktirme oranları gerektiren bir dizi uygulamalar için yüksek esneklik ve verimliliğe sahiptir. Bu çalışmada, düşük karbonlu çelik telden gaz metal ark kaynağı (GMAW) tabanlı eklemeli imalat uygulanarak üretilen parça mekanik özelliklerinin (çekme dayanımı ve mikrosertlik) deformasyon hızına göre değişimi araştırılmıştır. Bu bağlamda, eklemeli imalat parçadan dikiş yönüne dik ve paralel olarak hazırlanan numunelere $1 \mathrm{ve} 4 \mathrm{~mm} / \mathrm{sn}$ hızlarında çekme deneyleri uygulanmıştır. Kaynak dikiş yönüne dik numunelerde, süneklikteki anizotropik davranış yüzünden deformasyon hızının artmasıyla çekme dayanımında artış görülürken yüzde uzama miktarlarında azalma belirlenmiştir. Çekme hızının dört kat artmasıyla dikiş yönüne paralel numunede çekme dayanımı ortalama $545 \mathrm{MPa}$, dik numunede ise $524 \mathrm{MPa}$ olarak elde edilmiştir. Dikiş yönüne paralel numunede orijinal numuneye göre çekme deformasyonundan kaynaklanan mikrosertlikte artış olmuştur. Deformasyon oranlarına göre bu artış $1 \mathrm{~mm} / \mathrm{sn}$ ve $4 \mathrm{~mm} / \mathrm{sn}$ için sırasıyla ortalama $\% 56$ ve $\% 64$ olarak hesaplanmıştır. Dikiş yönüne dik numunelerde, bu oranlamada bir miktar azalma olsa da orijinal numuneye göre mikrosertlik değerlerindeki artış sırasıyla $\% 46$ ve $\% 53$ olarak belirlenmiştir.

https://dx.doi.org/10.30855/gmbd.2021.03.01

\section{Mechanical Properties of Low Carbon Steel Produced by GMAW-based Additive Manufacturing}

\section{ARTICLE \\ INFO}

Received: 08.09.2021

Accepted: 02.11.2021

Keywords:

Additive

manufacturing

Low-carbon steel

WAAM

Mechanical properties

Deformation speed

\begin{abstract}
Wire arc additive manufacturing has high flexibility and efficiency, especially for the economical production of large-size metal parts and a range of applications that require relatively high deposition rates. In this study, the variation of the mechanical properties (tensile strength and microhardness) of the part produced by gas metal arc welding (GMAW) based additive manufacturing from low carbon steel wire according to the deformation rate was investigated. In this context, tensile tests at 1 and $4 \mathrm{~mm} / \mathrm{sec}$ speeds were applied to the samples prepared perpendicular and parallel to the seam direction from the additive manufacturing part. In the samples perpendicular to the weld seam direction, an increase in tensile strength was observed with an increase in the deformation rate due to the anisotropic behavior in ductility, while a decrease in percent elongation was determined. With the increase of the tensile speed four times, the average tensile strength of the sample parallel to seam direction was $545 \mathrm{MPa}$, and the vertical specimen was $524 \mathrm{MPa}$. In the sample parallel to the seam direction, there was an increase in microhardness resulting from tensile deformation compared to the original sample. This increase relative to the deformation rates was calculated as $56 \%$ and $64 \%$ on average for $1 \mathrm{~mm} / \mathrm{sec}$ and 4 $\mathrm{mm} / \mathrm{sec}$, respectively. Although there was a slight decrease in this ratio in samples perpendicular to the seam direction, the increase in microhardness values compared to the original sample was determined as $46 \%$ and $53 \%$, respectively.
\end{abstract}

https://dx.doi.org/10.30855/gmbd.2021.03.01

*Corresponding author: mgunay@karabuk.edu.tr

To cite this article: M. Günay and İ. Yeşildağ, "Mechanical Properties of Low Carbon Steel Produced by GMAW-based Additive Manufacturing", Gazi Journal of Engineering Sciences, vol.7, no.3, pp. 175-182, 2021. doi:10.30855/gmbd.2021.03.01 


\section{INTRODUCTION (GIRIŞ)}

Additive manufacturing (AM), well-known as rapid prototyping and $3 \mathrm{D}$ printing, is a modern method that enables part production by combining materials in layers, unlike traditional machining methods. AM technology has many advantages for example the production of parts with complex geometry, fast production, low cost, efficient use of materials, and is suitable for remote production. However, the disadvantages of AM are that it is more costly than mass production in large numbers, limited material type and part size, and post-production machining applications such as heat treatment, machining, etc.[1].At the same time, these methods allow the repair of a damaged part. AM methods cover a wide variety of materials such as plastics, metals, composites, ceramics, and have begun to be used effectively in the production of various parts in important industrial areas such as aviation, health, dentistry, jewelry, marine and energy [2]. AM methods include laser beam melting (LBM), direct metal laser sintering/melting (DMLS/E), spark plasma sintering (SPS), selective laser melting (SLM), electron beam melting (EBM), laser engineered mesh forming (LENS), and wire arc additive manufacturing (WAAM) technologies are used in the manufacture of metal parts.

WAAM is a cost-effective and convenient technique for the rapid production of large and medium-sized components and structures. This method uses classic arc-based welding equipment for multilayer deposition in a layered manner to create large structures and parts [3]. Productions with WAAM may exhibit better mechanical properties than machined industrial grades. The applicability of this technique has been verified with materials ranging from titanium, aluminum, stainless steel to Inconel. Compared to other additive manufacturing techniques, WAAM has low equipment costs, reduced lead time, high deposition rates and density components [4], [5]. It is also preferred for its minimum resource and energy requirements. All these favorable features support the applicability of WAAM in the aerospace, automobile and medical industries. Also, the high deposition rate leads to lower resolution and wavy surface quality, respectively. It is imperative to be careful and prepared when working with wire arc additive manufacturing due to the high heat input limiting material selection [6]. The WAAM technique is suitable for a range of applications that require a near net shape, freedom of design, economical production of large-size metal parts, and relatively high deposition rates. Reduced material wastage and production time compared to traditional manufacturing methods creates additional advantages and opportunities for hybrid manufacturing, the production of functionally graded materials, and moderately complex parts [7]. On the other hand, the entire manufacturing process, from understanding and interpreting part models to the design and preparation of a manufacturing process, requires skilled operators. However, the WAAM process provides a high degree of flexibility and economic efficiency than traditional welding, coating or subtractive manufacturing techniques [8]. Multi-pass weld reduces wastage and offers much faster speeds than powder-based additive manufacturing (AM) techniques. The deposition rate of WAAM technology using the GMAW process is two to three times higher than plasma arc welding (PAW) or gas tungsten arc welding (GTAW) based techniques [9].

In recent years, some of the researches on the mechanical properties of parts produced with WAAM technology from various metal materials are summarized below. Duraisamy et al. produced a $4 \mathrm{~mm}$ thick plate by feeding ER347 stainless steel wire $(\mathrm{d}=1.2 \mathrm{~mm})$ with WAAM parameters such as different current and welding speed. As a result of the investigations, it was stated that the thermal transitions during the formation of the plate showed better ductility and anisotropic properties matched to the industrial quality (AISI 347). While the microhardness of WAAM-produced plates gradually changed in the range of 203.5-248.2 HV along the deposition direction, it was stated that the tensile strength changed at 0 and $90^{\circ}$ orientation angles [10]. Queguineur et al. investigated the usability of $316 \mathrm{~L}$ steel and $\mathrm{Cu}-\mathrm{Al}$ alloy materials in the WAAM method to reduce manufacturing errors in large castings for marine vessels. The part produced by cold metal transfer assisted welding technology was examined in terms of production time, corrosion and mechanical properties. Tests on $316 \mathrm{~L}$ stainless steel created results close to the mechanical properties of typically welded joints in welding procedure qualification reports. However, it has been stated that there is a slight decrease in the yield and tensile strength of the $\mathrm{Cu}-\mathrm{Al}$ alloy material [11]. Wang et al. performed WAAM studies with $316 \mathrm{~L}$ stainless steel $(\varnothing 1.2 \mathrm{~mm}$ wire) at different arc modes and at a constant deposition rate, examining structural integrity, microstructures, and mechanical properties. Even though the deposition rate and scanning rate of SpeedPulse and SpeedArc WAAM are the same, the SpeedArc technique has been found to have lesser heat input and upper cooling rate. Thanks to its lesser heat input and finer solidification structure, the part 
produced with this technique has more tensile strength and hardness than a component produced with the SpeedPulse technique [12]. Lin et al. investigated the microstructure and mechanical properties of the material deposited by XC-45 cored metal wires. The mechanical properties of the XC-45 part produced by WAAM and the AISI 1045 part produced via conventional processes were compared. It was stated that the hardness of the part increased from bottom to top, and the mean hardness of the lower, middle and upper regions was measured as $238 \mathrm{HV}, 243 \mathrm{HV}$ and $250 \mathrm{HV}$, respectively. As a result of the tensile tests, the average yield/tensile strength was determined as $620 \mathrm{MPa} / 817 \mathrm{MPa}$ in the parallel direction and 580 $\mathrm{MPa} / 615 \mathrm{MPa}$ in the perpendicular direction [13]. Le et al. investigated the effects of deposition strategy and heat input on the shape and microstructure development of thin-walled components in the GMAW-based additive manufacturing process from ER70S-6 steel wire. The results showed that the alternative deposition direction strategy (opposite deposition directions of two neighboring layers) is more suitable for constructing thin walls of relatively regular height. The microstructure of the walls led to variation in hardness from top to bottom (157-192 HV5). Therefore, the stress behaviors of the constructed material also demonstrated anisotropic properties, with yield strength and tensile strength varying between 320-362 $\mathrm{MPa}$ and 429-479 $\mathrm{MPa}$, respectively [14].

When both the review and research studies on steel materials by wire arc additive manufacturing are examined, it is seen that there are many process parameters that affect the size, microstructure and mechanical properties of thick and/or thin-walled parts produced with WAAM technology. In order to improve the database in terms of optimization of the inlet heat setting and process parameters, which directly affect the thermomechanical process mechanism that develops during the deposition process, more investigations based on the WAAM method are required. In the present research, the mechanical properties of the part manufactured from SG2 (ER70S-6) steel wire by using the GMAW method were investigated. In addition to the literature in this research, the changes in the mechanical properties of the steel material produced with WAAM according to the deformation rate were compared.

In this research, low carbon $(1 \mathrm{~mm})$ steel material with the code G42 3CMG3Si1 according to TS EN ISO 14341-A and produced as welding wire with the code SG2 by Askaynak was chosen. M20 welding gas was used during the welding process.
Some mechanical properties of the material and the chemical composition of the welding gas are given in Table 1 .

\section{MATERIAL AND INVESTIGATION METHODOLOGY (MATERYAL VE ARAŞTIRMA METODOLOJISI)}

In this research, low carbon $(1 \mathrm{~mm})$ steel material with the code G42 3CMG3Si1 according to TS EN ISO 14341-A and produced as welding wire with the code SG2 by Askaynak was chosen. M20 welding gas was used during the welding process. Some mechanical properties of the material and the chemical composition of the welding gas are given in Table 1.

Table 1. Mechanical properties and welding gas chemical composition (SG2 mekanik özellikleri ve kaynak gazı kimyasal bileşimi) [15]

\begin{tabular}{|c|c|c|c|}
\hline \multicolumn{4}{|c|}{ Mechanical properties } \\
\hline $\begin{array}{c}\text { Yield } \\
\text { strength }\end{array}$ & $\begin{array}{c}\text { Tensile } \\
\text { strength }\end{array}$ & Elongation & $\begin{array}{l}\text { Notch impact } \\
\text { strength }\end{array}$ \\
\hline $440 \mathrm{MPa}$ & $540 \mathrm{MPa}$ & $\% 30$ & $60 \mathrm{~J}(-30)$ \\
\hline \multicolumn{4}{|c|}{ Welding gas chemical composition (\%) } \\
\hline Ar-80 & $\mathrm{O}_{2}-8$ & $\mathrm{CO}_{2}-12$ & \\
\hline
\end{tabular}

A Fronius Transpuls Synergic 3200 model MIG/MAG welding machine was adapted to the Kuka KR10R1420 model robot to produce parts with the additive manufacturing technique. Welding parameters were decided as a result of preliminary experiments, taking into account the Fronius Weld Connect software and the thickness of the base plate. In the WAAM process, $10 \mathrm{~mm}$ S235JR steel material was used as the base plate and the surface was grinded before the welding process and the oil, dirt and corrosive layer on the surface was cleaned. During the welding process, the pass temperature was controlled with the Sinometer BM380 laser infrared temperature measuring device. The parameters used for the welding process are given in Table 2.

Table 2. Welding parameters (Kaynak parametreleri)

\begin{tabular}{|l|l|}
\hline Current & $218 \mathrm{~A}$ \\
\hline Wire feed speed & $11 \mathrm{~m} / \mathrm{min}$ \\
\hline Voltage & $22.5 \mathrm{~V}$ \\
\hline Gas flow rate & $151 / \mathrm{min}$ \\
\hline Distance of torch to workpiece & $13 \mathrm{~mm}$ \\
\hline
\end{tabular}

The dimensions of the steel part produced by wire arc additive manufacturing were chosen as 120x120x12 mm. The part manufacturing process was carried out at room temperature, and the torch was 
always held at a right angle during the welding process. Also, attention was taken to keep the transition temperature below $150^{\circ} \mathrm{C}$ in order to minimize the effects that may occur due to heat and to prevent the expansion of the weld pool [16]. During the WAAM, a $60 \mathrm{sec}$ pause was applied between the deposited of one weld seam and the next, and the final cooling of the part was carried out in calm air at room temperature. On the other hand, it was stated that the weld seam is formed in the form of an indentedprotruding surface of $1-2 \mathrm{~mm}$ on average in the WAAM method, and this defect can only be removed by machining from all surfaces of the part [17]. Therefore, in order to better evaluate the tensile strength of the part produced with WAAM technology, $1.5 \mathrm{~mm}$ depth of chip was removed from all surfaces of the part before preparing test samples according to the standard (ISO 6892-1-2009). Then, tensile test specimens were prepared in parallel and perpendicular to the weld seam by wire electrical discharge machining from the middle part of the additive manufacturing part.

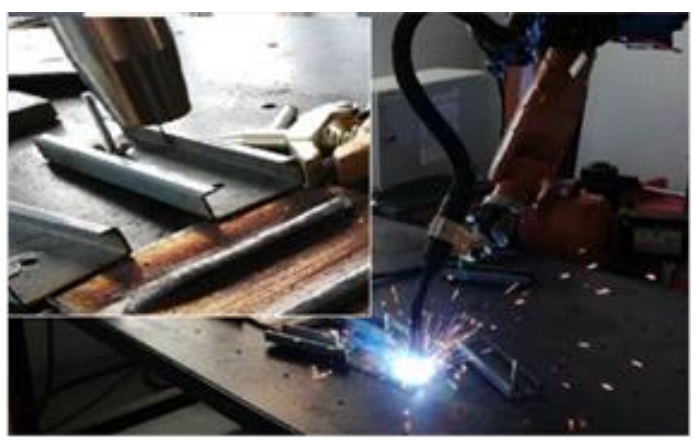

Figure 1. Experimental environment image (Deney ortamı görüntüsü)

\section{RESULTS AND DISCUSSION (SONUÇLAR VE TARTISSMA)}

\subsection{Tensile Strength (Çekme Dayanımı)}

Tensile tests were carried out at $1 \mathrm{~mm} / \mathrm{sec}$ and 4 $\mathrm{mm} / \mathrm{sec}$ speeds on samples cut parallel and perpendicular to the weld seam. The tensile test graph of the sample cut parallel to the seam direction from the part produced by additive manufacturing is shown in Figure 2. In the graphs, lines 1 and 2 are the stressstrain curves for the samples applied tensile test at 1 $\mathrm{mm} / \mathrm{sec}$, and lines 3 and 4 at $4 \mathrm{~mm} / \mathrm{sec}$.

As a result of the experiments, the yield strength of the samples was determined as $402 \mathrm{MPa}$, and the tensile strength was determined as $530 \mathrm{MPa}$, at a deformation rate of $1 \mathrm{~mm} / \mathrm{sec}$. The rupture occurred as a result of an average elongation of $33 \%$ in the samples. When this result is compared with the SG2 material, the mechanical features of which are given in Table 1, it is seen that there is a decrease in the yield strength of the additive manufacturing part and an increase in the tensile strength. As a result of the tensile process at a speed of $4 \mathrm{~mm} / \mathrm{sec}$, average yield strength of $417 \mathrm{MPa}$, a tensile strength of $545 \mathrm{MPa}$, and an elongation of $32 \%$ were obtained. It is possible to explain this change in yield and tensile strength according to the deformation rate with the classical dislocation mechanism. The increase in the dislocation density in metal materials according to the load makes the plastic deformation process difficult. This process cause the mechanical properties of the material to improve [18]. In the present study, the increase in the deformation rate increased the yield and tensile strength of the part manufactured with WAAM technology, similar to the literature [19].

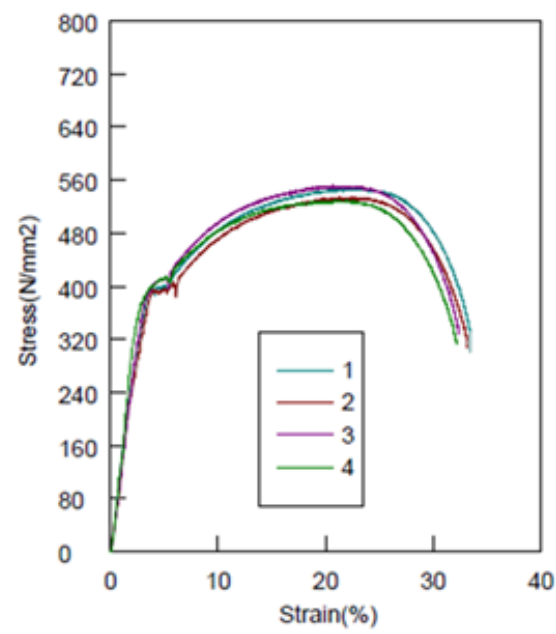

Figure 2. Tensile plot of the sample parallel to seam direction (Dikiş yönüne paralel numunenin çekme grafiği)

The stress-strain curves of the samples prepared perpendicular to the weld seam are given graphically in Figure 3. When the tensile test results of the samples perpendicular to the weld seam were examined, an elongation of $32.2 \%$ was obtained with an average yield of $353 \mathrm{MPa}$ and tensile strength of $498 \mathrm{MPa}$ at a deformation rate of $1 \mathrm{~mm} / \mathrm{sec}$. When these values are compared with the results of the samples in the direction parallel to the weld seam, it can be seen that there is a decrease in yield and tensile stresses. This result is compared with the mechanical properties given for SG2 welding wire, it was determined that there was only a slight increase in the amount of elongation (Table 1). When the tensile process at a speed of $4 \mathrm{~mm} / \mathrm{sec}$ was applied to the samples prepared in the direction perpendicular to the seam, the yield stress of $382 \mathrm{MPa}$ and tensile stress of $524 \mathrm{MPa}$ were achieved. The elongation amount of the 
samples was measured as $26.7 \%$ on average, which is $17.08 \%$ lower than the percent elongation amount of the samples pulled at low speed. The low elongation in vertical samples indicates anisotropic property in ductile behavior. This characteristic in ductility usually occurs in additively fabricated parts and has been stated in many researches for numerous metals and alloys [12, 20]. On the other hand, it is an indication that the formability decreases due to the dislocation mechanism at high deformation speed in part produced by the WAAM technique.

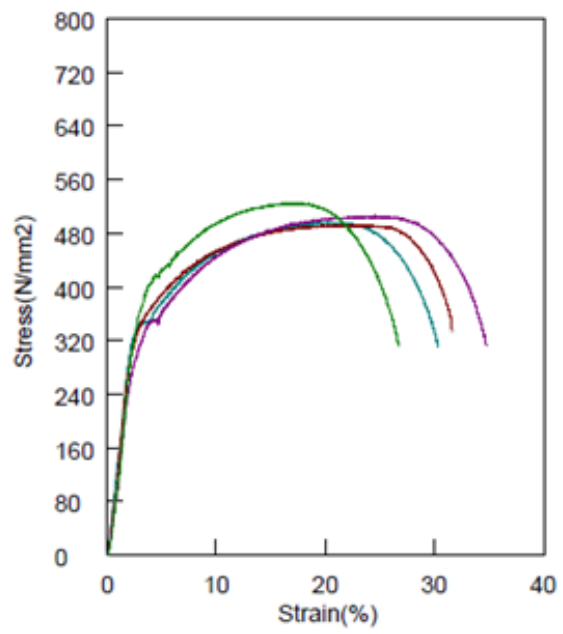

Figure 3. Tensile plot of the sample perpendicular to seam direction (Dikiş yönüne dik numunenin çekme grafĭ̌i)

When the percentage elongation amounts are evaluated collectively, 3\% more elongation was observed in the tensile specimens prepared parallel to the weld direction for a deformation rate of $1 \mathrm{~mm} / \mathrm{sec}$ compared to the specimens perpendicular. In the tensile process at $4 \mathrm{~mm} / \mathrm{sec}$, the specimens parallel to the weld seam direction exhibited $19.8 \%$ more elongation. Although there are similar results in the literature [21, 22], the possible excess of possible porosities and heterogeneous microstructure distribution in samples perpendicular to seam direction are thought to be the main reason for this result. On the other hand, if the tensile graphs obtained from the samples in the direction parallel and perpendicular to the weld seam are carefully examined, it can be seen that there is a striking difference in yield stress. It can be said that the yield behavior is explicit in the samples prepared in the direction parallel to the seam, and it is not explicit in the direction perpendicular to the seam except for the sample no 1. This result in yield stress behavior is related to whether the $\mathrm{C}$ atom is in free form in the solid solution [23]. In addition, this indicates low homogeneity and metallurgical structural differences in samples perpendicular to the weld seam. As it is known, in multi-pass welding processes applied on top of each other in the welding process, each pass causes the ductility to increase by exposing the previously deposited material to heat treatment. Consequently, in multi-run welding, microstructural differences occur due to heterogeneous heat dissipation, which often negatively affects mechanical properties [24].

\subsection{Microhardness (Mikrosertlik)}

The microhardness of the GMAW-based additive manufacturing part was measured by applying the Vickers method on samples parallel and perpendicular to the weld seam before and after tensile deformation. The measurement was carried out for 15 seconds and under a load of $5 \mathrm{~kg}$. The pictures given in Figure 4 show the samples with microhardness measurement before and after tensile deformation. The average values of the results obtained from the measurements made from 5 different places with $0.5 \mathrm{~mm}$ spacing from the rupture surfaces of the samples were evaluated graphically. The hardness results of the 1 $\mathrm{mm} / \mathrm{sec}$ (Deform-1) and $4 \mathrm{~mm} / \mathrm{sec}$ (Deform-2) samples and the samples without tensile deformation (Original) are shown in Figures 5 and 6 for the specimens in parallel and perpendicular, respectively.

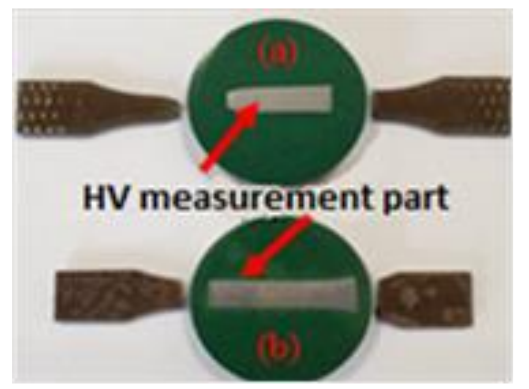

Figure 4. Microhardness measurement samples a) After deformation, b) Original (Mikrosertlik ölçüm

numuneleri, a) Deformasyon sonrasi, b) Orijinal)

The blue-colored line in Figure 5 shows the microhardness changes of the specimens without tensile deformation, the red line at $1 \mathrm{~mm} / \mathrm{sec}$ and the green line at $4 \mathrm{~mm} / \mathrm{sec}$. The original microhardness value of the samples produced by WAAM was measured to be $156 \mathrm{HV}$ on average. When the graph is examined, it is seen that the hardness of the samples subjected to tensile deformation is quite close among themselves and higher than the samples without the tensile test. As emphasized in the literature [25], the strain hardening that occurred in the case of a high deformation rate increased the microhardness by triggering an increase in the dislocation density. For this reason, the microhardness of the samples 
subjected to tensile deformation was obtained higher. Similarly, an increase in the hardness of the WAAM part occurred as the deformation rate increased from 1 $\mathrm{mm} / \mathrm{sec}$ to $4 \mathrm{~mm} / \mathrm{sec}$ (Figure 5). Compared to the microhardness of the original sample, the microhardness values of the samples subjected to deformation increased by an average of $56 \%$ and $64 \%$ for 1 and $4 \mathrm{~mm} / \mathrm{sec}$, respectively.

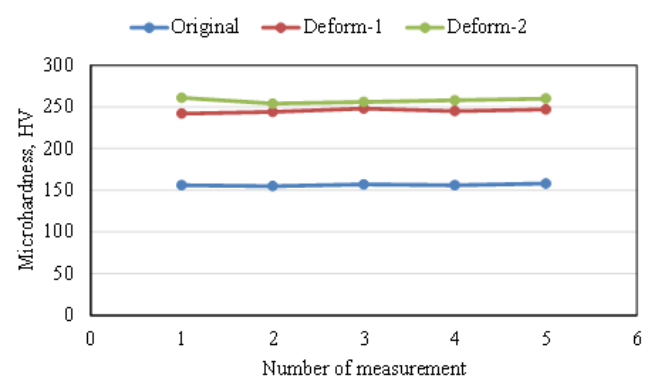

Figure 5. Hardness of the sample parallel to seam direction (Dikiş yönüne paralel numunenin sertliği)

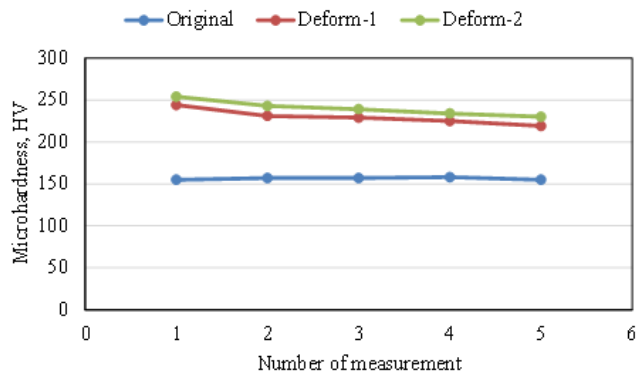

Figure 6. Hardness of the sample perpendicular to seam direction (Dikiş yönüne dik numunenin sertliği)

As seen from Figure 6, the microhardness changes, in general, are similar to those of the samples parallel to the seam direction. On the one hand, while the undeformed (original) specimens gave very close results in both directions, differences were observed in the microhardness values of the specimens subjected to tensile deformation in the parallel and perpendicular directions to the weld seam. The hardness values of the samples perpendicular to seam direction were lower than those of the parallel samples. The main reason for this result, as emphasized in the tensile test results, is the anisotropic properties and microstructural differences due to the welding thermal cycle (melting-cooling) [22, 24]. On the other hand, the increased strength by reason of the dislocation mechanism occurred with the increase of the tensile deformation rate from 1 to $4 \mathrm{~mm} / \mathrm{sec}$ resulted in an increase in the hardness of the material. In the direction perpendicular to the weld seam, the microhardness of the specimens subjected to tensile strain compared to the original specimen is an average increase of $46 \%$ and $53 \%$ for $1 \mathrm{~mm} / \mathrm{sec}$ and $4 \mathrm{~mm} / \mathrm{sec}$, respectively. In addition, the consistency ( $\pm 3 \mathrm{HV}$ ) in the microhardness changes of the original samples is attributed to the homogeneous microstructure distribution within all layers accumulated from the bottom to the top of the thick piece produced by WAAM $[14,26]$.

\section{CONCLUSIONS ANDRECOMMENDATIONS (SONUÇLAR VE ÖNERILER)}

In this research, the mechanical properties of a thick-walled steel piece produced by applying WAAM technology based on GMAW method integrated with an industrial welding robot were investigated. The results obtained are summarized below:

- In general, the mechanical properties of the parts produced by additive manufacturing have been improved by increasing the deformation rate. On the other hand, while the samples in the direction parallel to the weld seam showed significant yielding behavior according to the deformation rate, some of the samples in the direction perpendicular to the weld showed insignificant yielding.

- The average tensile strength was determined as 530 MPa for the specimen parallel to the seam and 498 MPa for the specimen perpendicular to the seam at a deformation rate of $1 \mathrm{~mm} / \mathrm{sec}$. Similarly, the tensile strength of the specimen perpendicular to the seam decreased when the deformation rate increased fourfold.

- While the microhardness of the samples prepared in the direction parallel to the seam was measured at an average of $245 \mathrm{HV}$ for $1 \mathrm{~mm} / \mathrm{sec}$, it was determined as $229 \mathrm{HV}$ in the vertical sample. When the deformation rate increased, this change in microhardness values was measured as $257 \mathrm{HV}$ and $240 \mathrm{HV}$, respectively.

- In the future, studies can be conducted on the fracture behavior of parts produced by GMAW-based wire arc additive manufacturing. More importantly, a lot of research needs to be done on the optimization of WAAM production parameters to reduce secondary operations to improve part size, surface quality and/or metallurgical structure homogeneity.

\section{CONFLICT OF INTEREST STATEMENT (ÇIKAR ÇATIŞMASI BÍLDIRIMI)}

The authors declare that there is no conflict of interest. 


\section{REFERENCES (KAYNAKLAR)}

[1] H. Dedeakayoğulları and A. Kacal, "Eklemeli İmalat Teknolojileri ve Kullanılan Talaşlı İmalat Yöntemleri," Imalat Teknol. ve Uygulamalarl, vol. 1, no. 1, pp. 1-12, 2020.

[2] M.Y. Kayacan and N. Yılmaz, "DMLS Eklemeli İmalatta Süreç Ve Maliyet Modeli Geliştirilmesi," J. Polytech., vol. 0900, no. 3, pp. 763-770, 2018, doi: 10.2339/politeknik.428093.

[3] J.J. Lewandowski and M. Seifi, "Metal Additive Manufacturing: A Review of Mechanical Properties," Annu. Rev. Mater. Res., vol. 46, no. April, pp. 151186, 2016, doi: 10.1146/annurev-matsci-070115032024.

[4] F. Martina, J. Mehnen, S.W. Williams, P. Colegrove and F. Wang, "Investigation of the benefits of plasma deposition for the additive layer manufacture of Ti-6Al-4V," J. Mater. Process. Technol., vol. 212, no. 6, pp. 1377-1386, 2012, doi: 10.1016/j.jmatprotec.2012.02.002.

[5] B. Cong, R. Ouyang, B. Qi and J. Ding, "Influence of cold metal transfer process and its heat input on weld bead geometry and porosity of aluminum-copper alloy welds," Xiyou Jinshu Cailiao Yu Gongcheng/Rare Met. Mater. Eng., vol. 45, no. 3, pp. 606-611, 2016, doi: 10.1016/s1875-5372(16)300807.

[6] C.R. Cunningham, J.M. Flynn, A. Shokrani, V. Dhokia and S.T. Newman, "Invited review article: Strategies and processes for high quality wire arc additive manufacturing," Addit. Manuf., vol. 22, no. June, pp. 672-686, 2018, doi: 10.1016/j.addma.2018.06.020.

[7] J.L. Prado-Cerqueira, J.L. Diéguez and A.M. Camacho, "Preliminary development of a Wire and Arc Additive Manufacturing system (WAAM)," Procedia Manuf., vol. 13, pp. 895-902, 2017, doi: 10.1016/j.promfg.2017.09.154.

[8] M. Chaturvedi, E. Scutelnicu, C.C. Rusu, L.R. Mistodie, D. Mihailescu and S. Arungalai Vendan, "Wire arc additive manufacturing: Review on recent findings and challenges in industrial applications and materials characterization," Metals (Basel)., vol. 11, no. 6, 2021, doi: 10.3390/met11060939.

[9] D. Ding, Z. Pan, D. Cuiuri and H. Li, "A multibead overlapping model for robotic wire and arc additive manufacturing (WAAM)," Robot. Comput. Integr. Manuf., vol. 31, pp. 101-110, 2015, doi: 10.1016/j.rcim.2014.08.008.

[10] R. Duraisamy, S. Mohan Kumar, A. Rajesh Kannan, N. Siva Shanmugam and K. Sankaranarayanasamy, "Reliability and sustainability of wire arc additive manufactured plates using ER 347 wire-mechanical and metallurgical perspectives," Proc. Inst. Mech. Eng. Part C J. Mech. Eng. Sci., vol. 235, no. 10, pp. 1860-1871, 2021, doi: $10.1177 / 0954406219861136$.

[11] A. Queguineur, G. Rückert, F. Cortial and J.Y. Hascoët, "Evaluation of WAAM for large-sized components in naval applications_NavalGroup_2017," Weld. World, vol. 62, no. 2, pp. 259-266, 2017.

[12] L. Wang, J. Xue and Q. Wang, "Correlation between arc mode, microstructure, and mechanical properties during wire arc additive manufacturing of 316L stainless steel," Mater. Sci. Eng. A, vol. 751, no. November, pp. 183-190, 2019, doi: 10.1016/j.msea.2019.02.078.

[13] Z. Lin, C. Goulas, W. Ya and M.J.M. Hermans, "Microstructure and mechanical properties of medium carbon steel deposits obtained via wire and arc additive manufacturing using metal-cored wire," Metals (Basel)., vol. 9, no. 6, 2019, doi: 10.3390/met9060673.

[14] V.T. Le, D.S. Mai and Q.H. Hoang, "A study on wire and arc additive manufacturing of low-carbon steel components: process stability, microstructural and mechanical properties," J. Brazilian Soc. Mech. Sci. Eng., vol. 42, no. 9, pp. 1-11, 2020, doi: 10.1007/s40430-020-02567-0.

[15] İ. Yeşildağ, "Düşük alaşimli çelikten tel ark eklemeli imalat ile üretilen bir parçanin mekanik özelliklerinin incelenmesi," Yüksek Lisans Tezi, Lisansüstü Eğitim Enstitüsü, Karabük Üniversitesi, 2020.

[16] T. Wang, Y. Zhang, Z. Wu and C. Shi, "Microstructure and properties of die steel fabricated by WAAM using H13 wire," Vacuum, vol. 149, pp. 185-189, 2018, doi: 10.1016/j.vacuum.2017.12.034.

[17] A. Busachi, J. Erkoyuncu, P. Colegrove, F. Martina and J. Ding, "Designing a WAAM based manufacturing system for defence applications," 
Procedia CIRP, vol. 37, no. October, pp. 48-53, 2015, doi: 10.1016/j.procir.2015.08.085.

[18] Q. Kun, Y. Li-Ming and H. Shi-Sheng, "Mechanism of Strain Rate Effect Based on Dislocation Theory," Chinese Phys. Lett., vol. 26, no. 3, p. 036103, Mar. 2009, doi: 10.1088/0256307X/26/3/036103.

[19] J.H. Kim, D. Kim, H.N. Han, F. Barlat and M.G. Lee, "Strain rate dependent tensile behavior of advanced high strength steels: Experiment and constitutive modeling," Mater. Sci. Eng. A, vol. 559, pp. 222-231, 2013, doi: 10.1016/j.msea.2012.08.087.

[20] Q. Zhang, J. Chen, Z. Zhao, H. Tan, X. Lin and W. Huang, "Microstructure and anisotropic tensile behavior of laser additive manufactured TC21 titanium alloy," Mater. Sci. Eng. A, vol. 673, pp. 204212, 2016, doi: 10.1016/j.msea.2016.07.040.

[21] X. Xu, S. Ganguly, J. Ding, S. Guo, S. Williams and F. Martina, "Microstructural evolution and mechanical properties of maraging steel produced by wire + arc additive manufacture process," Mater. Charact., vol. 143, no. December, pp. 152-162, 2018 , doi: 10.1016/j.matchar.2017.12.002.

[22] A. Lopez, R. Bacelar, I. Pires, T.G. Santos, J.P. Sousa and L. Quintino, "Non-destructive testing application of radiography and ultrasound for wire and arc additive manufacturing," Addit. Manuf., vol. 21, no. April 2019, pp. 298-306, 2018, doi: 10.1016/j.addma.2018.03.020.
[23] M. Türkmen, S. Gündüz, "Çift fazli çeliklerde martenzit morfolojisinin statik deformasyon yaşlanma davranişi üzerine etkisi," J. Fac. Eng. Archit. Gazi Univ., vol. 28, no. 2, pp. 353-362, 2013.

[24] C.V. Haden, G. Zeng, F.M. Carter, C. Ruhl, B.A. Krick and D.G. Harlow, "Wire and arc additive manufactured steel: Tensile and wear properties," Addit. Manuf., vol. 16, no. 2010, pp. 115-123, 2017, doi: 10.1016/j.addma.2017.05.010.

[25] P. Dirisu, G. Supriyo, F. Martina, X. Xu and S. Williams, "Wire plus arc additive manufactured functional steel surfaces enhanced by rolling," Int. J. Fatigue, vol. 130, no. December 2018, p. 105237 , 2020, doi: 10.1016/j.ijfatigue.2019.105237.

[26] N. Sridharan, M.W. Noakes, A. Nycz, L.J. Love, R.R. Dehoff and S. S. Babu, "On the toughness scatter in low alloy C-Mn steel samples fabricated using wire arc additive manufacturing," Mater. Sci. Eng. A, vol. 713, no. July 2017, pp. 18-27, 2018, doi: 10.1016/j.msea.2017.11.101.

This is an open access article under the CC-BY license (https://creativecommons.org/licenses/by/4.0/)

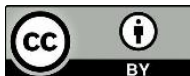

